\title{
A rice variety with a high straw biomass retained nitrogen and phosphorus without affecting soil bacterial species
}

\author{
Xinqiang Liang ${ }^{1, *}$, Fayong $\mathrm{Li}^{1}$, Sheng Wang ${ }^{2}$, Guifen Hua ${ }^{1}$, Miaomiao $\mathrm{He}^{3}$, Guangming Tian ${ }^{1}$, Sangar Khan ${ }^{1}$, \\ Ravin Poudel ${ }^{4}$, Karen A. Garrett ${ }^{4}$ \\ 1 College of Environmental and Resource Sciences, Zhejiang University, Hangzhou 310058, China \\ 2 College of Life Information Science and Instrument Engineering, Hangzhou Dianzi University, Hangzhou 310018, China \\ 3 Department of Life and Environmental Science, Hangzhou Normal University, Hangzhou 310036, China \\ 4 Plant Pathology Department, Institute for Sustainable Food Systems, and Emerging Pathogens Institute, University of Florida, Gainesville, \\ FL 32611, USA
}

\section{ARTICLE INFO}

\section{Article history:}

Received August 30, 2019

Revised January 4, 2020

Accepted March 5, 2020

\section{Keywords:}

Agricultural wetland

Network analysis

Nutrient

Rice variety

Soil bacterial communities

\begin{abstract}
A B S T R A C T
It is well documented that rice paddy fields act as agricultural wetlands that remove or retain nutrients; however, their associated effects on soil microbial communities are rarely reported. The present study evaluates the impact of rice variety on nutrient removal via plant uptake, nutrient retention in the soil, and bacterial associations in rice paddy fields, using a network analysis that compares the soil bacterial communities of two rice varieties. We found that the high-straw rice variety (YD-1) allows uptake of a high amount of nitrogen $(\mathrm{N})$ and phosphorus (P) from paddy rice fields via harvesting, but causes less residual total $\mathrm{N}$ and $\mathrm{P}$ to remain in the soil. However, both rice varieties (YD-1 and XS-134 (Xiushui-134)) had non-significant effects on the dominant bacterial taxa. The short-term response of bacterial community diversity to rice variety is found to be mainly due to less frequently recovered species. A network analysis that incorporates soil nutrients as nodes, along with bacterial taxa, found that only one node representing the total $\mathrm{P}$ related to the non-dominant species had an indirect association with the rice straw biomass. The observed short-term impact of the two rice varieties (XS-134 and YD-1) on soil bacterial diversity and nutrient surplus in these agricultural wetlands is limited under a high level of fertilization.
\end{abstract}

(C) Higher Education Press 2020

\section{Introduction}

Lowland rice paddy fields are agricultural wetlands that are important for both world food production and regional nutrient management (Jennings, 1974; Wang et al., 2012; Liang et al., 2014). However, in many rice cropping systems, nitrogen (N) and phosphorus $(\mathrm{P})$ fertilizers are applied in excess amounts

\footnotetext{
* Corresponding author

E-mail address: liang410@zju.edu.cn (X.Q. Liang)
}

(Tilman et al., 2002; Zhao et al., 2016). In the Taihu Lake region of south-eastern China, the $\mathrm{N}$ application rate in rice fields often has exceeded $200 \mathrm{~kg} \mathrm{~N} \mathrm{ha}^{-1}$, which is a higher fertilizer rate than those of other rice growing areas, such as California (Liang et al., 2014). Although researchers and local government authorities have started to raise awareness among farmers on the potential risk of nutrient runoff into the environment (Ju et al., 2009; Chen et al., 2015), farmers are still applying a high dose of fertilizers to obtain higher production. Thus, an alternative management practice is required to change the ecological function of rice fields from a 
nutrient export source to an interception sink (Liang et al., 2007; Xiong et al., 2015), such as via the removal or retention of soil nutrients by different plant varieties or genotypes (Bhadraray et al., 2002). Essentially, rice varieties with greater biomass compared to conventional varieties are able to remove excess nutrients from rice fields. It is hypothesized that such rice varieties may reduce the risks due to high fertilizer input, specifically by reducing the nutrient losses from paddy fields to the environment.

However, one serious concern is whether associated microbial community structure will be altered or absent in the soil after planting different rice varieties, especially given their important role in biogeochemical processes and nutrient availability in paddy fields (Balasooriya et al., 2016; Luo et al., 2019). Rice varieties of the paddy fields may affect microbial growth in the rhizosphere. For example, rice plants can affect the abundance of some phyla, such as Gemmatimonadetes, Proteobacteria, and Verrucomicrobia, and many functional groups, such as methanogens and methanotrophs (Conrad, 2007), potential iron reducers (e.g., Geobacter, Anaeromyxobacter), and fermenters (e.g., Clostridiaceae, Opitutaceae) (Breidenbach et al., 2016). Despite these previous investigations, key knowledge gaps remain that impede our understanding of the relationships between nutrients and associated soil microbial community structures under different rice varieties.

Moreover, residue removal from paddy fields may result in an adverse effect on soil microbes, as soil $C$ decreases annually. Some research studies have confirmed that soil $\mathrm{C}$ may control the soil microbial activity (Eisenhauer et al., 2010; Breulmann et al., 2012). The amount of stored carbon in soil reflects the balance between litter production of plant shoots and the root, and root exudates and their microbial decomposition (Lange et al., 2015). Residual removal may result in an opposite effect for the more active and abundant microbial community under increased plant residue inputs (Eisenhauer et al., 2010). Therefore, changes in soil microbes after straw removal requires more attention and potentially long-term observation. Plant diversity is a widespread concern due to changes in soil nutrient composition (Eisenhauer et al., 2010; Lange et al., 2015). Different rice varieties may have different uptake potential for soil nutrients, which may further cause changes in soil microbial composition.

Recently, the analysis of microbiome networks has been employed to reveal relationships among different microbial taxa (Faust and Raes, 2012). Network analysis supports the evaluation of direct and indirect associations among microbial taxa and other variables, such as nutrient levels or plant responses (Faust et al., 2012; Faust and Raes, 2012; Poudel et al., 2016). Previous studies have studied the nutrient cycling responses, to specific rice varieties in certain environments (Suriyagoda et al., 2014; Ye et al., 2014; Somaweera et al., 2016). Some studies have confirmed that the different acquisition behaviors of various rice varieties to nutrients depend on their genetic abilities and different responses to nutrient management practices, which may lead to differences in nutrient uptake (Dass et al., 2015; Harish et al., 2018). However, it is still unclear to what extent rice variety will affect nutrient removal via plant uptake, nutrient retention in soil, or associated soil microbial communities. The objectives of this study are i) to compare soil chemical and microbial composition in the rhizosphere of two rice varieties - a conventional rice variety Xiushui-134 (XS-134) and a newly released rice variety Yudao-1 (YD-1) with high straw yield; ii) to evaluate the direct and indirect associations among microbial taxa and nutrient removal and retention in the rice field.

\section{Materials and methods}

\subsection{Field experimental design and sample collection}

The experiment was carried out in Jingshan Town, Hangzhou City of the Zhejiang Province $\left(30^{\circ} 23^{\prime} \mathrm{N}, 119^{\circ} 54^{\prime} \mathrm{E}\right)$. The specific site represents the rice production area in the Taihu Lake region of eastern China with the typical climate characteristics of the coastal plain area. The total area of the experimental site is 18 ha with 18 subplots ( 1 ha each). Prior to 2016, there was a rice-fallow rotation system in these experimental subplots. The rice variety Xiushui-134 (XS-134) was grown in subplots. In 2016, the conventional rice variety (XS-134) and newly released rice variety (YD-1) with a high straw biomass by Zhejiang University were both planted and replicated in the 18 subplots. The soil of the experimental site was classified as hydragic paddy soil (silt loam, mixed, mesic Mollic Endoaquepts). Prior to rice planting in June 2016, 18 soil samples from 18 subplots were taken from the top $20-\mathrm{cm}$ layer. The averaged soil $\mathrm{pH}$, total $\mathrm{C}$, total $\mathrm{N}$, and total $\mathrm{P}$ were $5.84,23.33 \mathrm{~g} \mathrm{~kg}^{-1}, 2.65 \mathrm{~g} \mathrm{~kg}^{-1}$, and $0.48 \mathrm{~g} \mathrm{~kg}^{-1}$, respectively, for the soil planted with XS-134. Further, the values were 5.70, $22.53 \mathrm{~g} \mathrm{~kg}^{-1}, 2.97 \mathrm{~g} \mathrm{~kg}^{-1}, 0.42 \mathrm{~g} \mathrm{~kg}^{-1}$, respectively, for the soil planted with YD-1. Irrigation practices for all plots followed typical methods for flooded rice in the region (Liang et al., 2013). The floodwater depths in each plot fluctuated from 10 to $70 \mathrm{~mm}$ until rice maturity and the field was drained 30 days prior to harvest. In all subplots, $25 \mathrm{~d}$ old rice seedlings were transplanted at $150 \mathrm{~mm} \times 150 \mathrm{~mm}$ spacing. Urea-N, superphosphate- $\mathrm{P}$, and $\mathrm{KCl}-\mathrm{K}$ fertilizers were applied at 270 $\mathrm{kg} \mathrm{N} \mathrm{ha}^{-1}, 45 \mathrm{~kg} \mathrm{P}_{2} \mathrm{O}_{5} \mathrm{ha}^{-1}$, and $110 \mathrm{~kg} \mathrm{~K}_{2} \mathrm{O} \mathrm{ha}^{-1}$, respectively. The $N$ fertilizer was applied in three splits (3:1:1) at early tillering, peak tillering, and booting stage, respectively. Phosphorus and potassium fertilizers were applied once as a basal fertilizer.

At maturity, plants in three $1 \mathrm{~m}^{2}$ micro-plots in each subplot were harvested by hand, threshed, dried, and were collected for dry matter yield, such as total $\mathrm{C}, \mathrm{N}$, and $\mathrm{P}$ analyses in both straw and grain tissues. Following the rice harvest, the rice residues in each micro-plot was excavated together with the roots, by gently shaking off the soil from around the roots, and using a sterile glass piece to gently scrape the soil adhering to 
the roots into a sterile bag. Six soil samples were collected from the rice rhizoplane in each subplot and then mixed with each other at $-80^{\circ} \mathrm{C}$ for DNA extraction and PCR, while the other part was air-dried, grounded, and sieved for chemical analysis.

\subsection{Soil and plant analysis}

Soil $\mathrm{pH}$ was determined with a glass electrode $\mathrm{pH}$ meter (PHS-3C, Shanghai). Soil and plant total $\mathrm{C}$ and $\mathrm{N}$ were determined by an elemental analyzer (Vario MAX CNS, Elementar, Germany). Total soil $\mathrm{P}$ and total plant $\mathrm{P}$ were digested with $\mathrm{H}_{2} \mathrm{SO}_{4}-\mathrm{HClO}_{4}$ and $\mathrm{H}_{2} \mathrm{SO}_{4}-\mathrm{H}_{2} \mathrm{O}_{2}$ solutions at $250^{\circ} \mathrm{C}$, separately, and both were determined by the molybdenum-blue colorimetric method (Walker and Adams, 1958). Available $P$ in the soil was extracted with a $0.5 \mathrm{M}$ $\mathrm{NaHCO}_{3}$ solution and determined by the molybdenum-blue colorimetric method (Olsen and Sommers, 1982). Phosphorus species in soil samples were analyzed using solution ${ }^{31} \mathrm{P}$ NMR spectroscopy following the standard procedure of previous studies (Cade-Menun et al., 2010; Liang et al., 2017). A capillary that contains $10 \mathrm{mM}$ methylene diphosphonic acid (MDP, Sigma Aldrich) was regarded as an external standard. Concentration of the $P$ species was calculated via the equation described by Toor et al. (2003).

\subsection{Soil bacterial community analysis}

Soil bacterial communities from the rhizosphere of the two rice varieties (XS-134 and YD-1) were profiled by amplifying fragments of the 16S rRNA gene and sequenced using the Illumina MiSeq platform (Shanghai Meiji Biology Company, China). Microbial DNA was extracted from 18 samples using the E.Z.N.A. ${ }^{\circledR}$ DNA Kit (Omega Bio-tek, Norcross, GA, US) according to the manufacturer's protocols. The V4-V5 region of the bacterial $16 \mathrm{~S}$ rRNA gene was amplified by PCR $\left(95^{\circ} \mathrm{C}\right.$ for $2 \mathrm{~min}$; followed by 25 cycles at $95^{\circ} \mathrm{C}$ for $30 \mathrm{~s}, 55^{\circ} \mathrm{C}$ for $30 \mathrm{~s}$, and $72^{\circ} \mathrm{C}$ for $30 \mathrm{~s}$; and a final extension at $72^{\circ} \mathrm{C}$ for $5 \mathrm{~min}$ ) using primers 515F 5'-barcode-GTGCCAGCMGCCGCGG)-3 and 907R 5'-CCGTCAATTCMTTTRAGTTT-3' (Yin and Wang, 2016), where the barcode was an eight-base sequence that was unique to each sample. $\mathrm{PCR}$ reactions were performed in triplicate $20 \mu \mathrm{L}$ mixtures containing $4 \mu \mathrm{L}$ of $5 \times$ FastPfu buffer, $2 \mu \mathrm{L}$ of $2.5 \mathrm{mM}$ dNTPs, $0.8 \mu \mathrm{L}$ of each primer $(5 \mu \mathrm{M}), 0.4 \mu \mathrm{L}$ of FastPfu polymerase, and $10 \mathrm{ng}$ of template DNA. Amplicons were extracted from $2 \%$ agarose gels and purified using the AxyPrep DNA Gel Extraction Kit (Axygen Biosciences, Union City, CA, US) according to the manufacturer's instructions and quantified using QuantiFluor ${ }^{\text {TM }}$-ST (Promega, US). Purified amplicons were pooled in equimolar amounts and paired-end sequenced $(2 \times 250)$ on an Illumina MiSeq platform according to the standard protocols. Raw fastq files were demultiplexed and quality-filtered using QIIME (version 1.17) with the following criteria: i) the $300 \mathrm{bp}$ reads were truncated at any site that receives an average quality score of $<20$ over a $50 \mathrm{bp}$ sliding window, and the truncated reads that were shorter than
50 bp were discarded; (ii) the exact barcode was matched and reads that contain ambiguous characters were removed; and iii) only sequences that overlap longer than $10 \mathrm{bp}$ were assembled according to their overlap sequence. Reads that could not be assembled were discarded. The remaining sequences of all samples were rarefied to the same sequencing depth (15000 sequences per sample). Operational taxonomic units (OTUs) were clustered based on a $97 \%$ similarity cut-off using UPARSE (version $7.1 \mathrm{http}: / /$ drive $5 . c o m /$ uparse/) and chimeric sequences were identified and removed using UCHIME. The taxonomy of each $16 \mathrm{~S}$ rRNA gene sequence was analyzed by RDP Classifier (http://rdp. cme.msu.edu/) against the silva (SSU115) 16S rRNA database using a confidence threshold of $70 \%$ (Amato et al., 2013).

\subsection{Network construction}

The bacterial operational taxonomic units (OTUs) table was filtered to remove any OTUs that had a total abundance of less than 10 sequences across all samples or that were present in less than 5 sequences of the individual samples. Relationships among OTU nodes and those between OTUs and nodes that represent nutrients in soil and plants were evaluated and graphed using the CoNet app in Cytoscape software (v3.4.0). Co-occurrence network was constructed using a method explained by Lima-Mendez et al. (2015). We selected a Spearman correlation and Kullback-Leibler as dissimilarity measures. To compute $p$ values, permutation and bootstrap distributions were generated with 1000 repetitions each, by shuffling taxon abundances and resampling from samples with replacement, respectively. Permutations that were computed for Spearman correlations included a renormalization step, which mitigates compositional bias (ReBoot). Measure-specific $p$ values were merged using Brown's method (Brown, 1975) and multiple testing correction was done with the procedure developed by Benjamini and Hochberg (1995). Lastly, edges with an adjusted $p$ value of above 0.05 were ignored.

\subsection{Data analysis}

A least significant difference (LSD) test was used to monitor the significance difference among the results of the two rice varieties (XS-134 and YD-1). Spearman's correlation was analyzed to test the relationships among bacterial diversity and soil and plant factors in rice paddy fields.

\section{Results}

\subsection{Uptake of nutrients by rice plants}

At the end of the season, the rice variety YD-1 had greater uptake of nutrients, including $\mathrm{N}$ and $\mathrm{P}$, from the paddy wetland soils than did the rice variety $X S-134$ (Fig. 1). The average $N$ and $P$ uptake by YD-1 was 311 and $40.3 \mathrm{~kg} \mathrm{ha}^{-1}$, respectively, 
while the corresponding uptake by XS-134 was 231 and $29.8 \mathrm{~kg} \mathrm{ha}^{-1}$, respectively. The difference in nutrient uptake was mainly due to the significantly higher straw yield in the rice variety YD-1 than in XS-134 ( $p=0.001)$. The average straw yield in YD-1 was $12.62 \mathrm{t} \mathrm{ha}^{-1}$, which is $40.3 \%$ greater than that of XS-134. There were no significant differences in
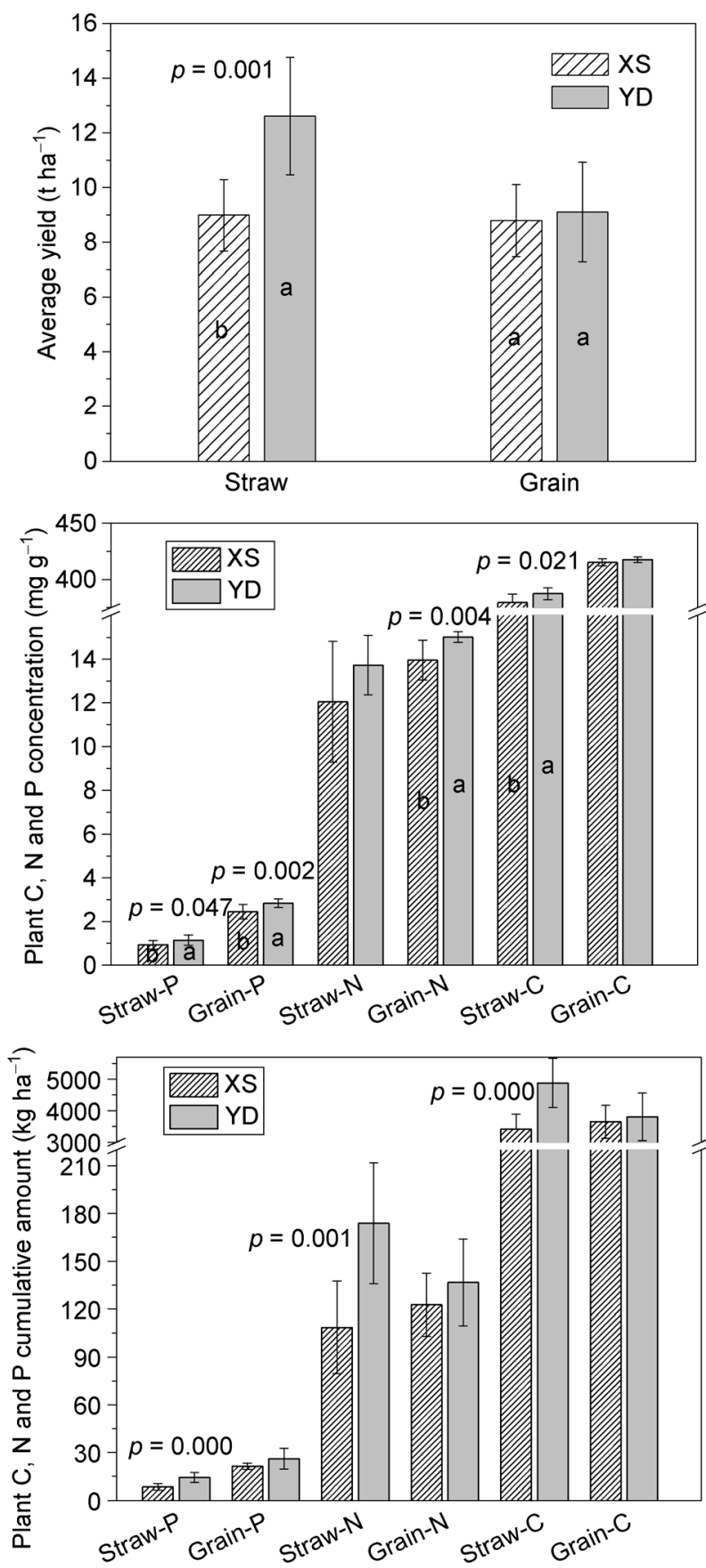

Fig. 1 Yield, contents and cumulative amount of $\mathrm{C}, \mathrm{N}$ and $P$ in straw and grain tissues of two rice varieties. Rice variety name XS indicates Xiushui-134, and YD indicates Yudao-1. the rice grain yield between the two rice varieties $(p>0.05$, Fig. 1).

\subsection{Residual soil nutrient content at the end of season}

At the end of the rice season, relatively lower residual content of total $\mathrm{N}(p<0.001)$ and total $\mathrm{P}(p=0.005)$ were observed in soil that was cultivated with YD-1 compared to with XS-134 (Table 1). For $\mathrm{P}$ species, ${ }^{31} \mathrm{P}-\mathrm{NMR}$ analysis showed that orthophosphate $(p=0.044)$ and phosphomonoesters (PME, $p$ $=0.033$ ) were more abundant in soil that was cultivated with XS-134. Orthophosphate was the most abundant form of $P$ in soil that was cultivated with XS-134 and YD-1 rice varieties, accounting for $60.9 \%-77.0 \%$ of the total extracted $P$ from the soil samples with mean values of $0.197 \mathrm{mg} \mathrm{g}^{-1}$ and 0.153 $\mathrm{mg} \mathrm{g}^{-1}$ for XS-134 and YD-1, respectively. However, the difference in the soil $P$ content - as measured by the Olsen $P$ method - between the two rice varieties was found to not be significant $(p>0.05)$. PME was the most important organic- $\mathrm{P}$ form in soil that was cultivated with both rice varieties (XS-134 and YD-1), accounting for $18.8 \%-32.5 \%$ of the total extracted $P$ from soil samples. In all soil samples, the abundance of other organic-P species, such as pyrophosphate and phosphodiesters (PDEs), was extremely low, and no significant difference was found between the two cultivars (XS-134 and YD-1) $(p>0.05)$.

\subsection{Soil bacterial communities under two rice varieties}

The high-abundance and low-abundance soil bacterial communities were clustered using the Bray-Curtis distance algorithm and the complete-linkage method. The similarities and differences among the communities from each soil sample are shown with a color gradient (Fig. 2). At the phylum level (Fig. 3), the soil bacterial communities of XS-134 and YD-1 are, respectively, Proteobacteria (33.7\% and $33.9 \%$ ), Chloroflexi (16.1\% and 16.5\%), Acidobacteria (12.8\% and $11.7 \%)$, Nitrospirae (11.3\% and $10.8 \%$ ), Bacteroidetes $(5.9 \%$ and $5.9 \%$ ), Chlorobi (3.5\% and $3.7 \%)$, Verrucomicrobia $(2.8 \%$ and $2.5 \%$ ), Actinobacteria (1.9\% and 1.9\%), and Firmicutes $(1.8 \%$ and $1.9 \%)$ (Table 2$)$. The sum of the sequences in Proteobacteria, Chloroflexi, Acidobacteria, and Nitrospirae accounts for $73.8 \%$ and $72.8 \%$ of the total sequences, respectively. At the genus level (Fig. 4), there were 45 and 44 genera in the soil samples of XS-134 and YD-1 with a soil bacterial community frequency higher than $0.5 \%$. The dominant species with a frequency above $2 \%$ in the soil samples of both XS-134 and YD-1 were Nitrospira, Anaerolineaceae_uncultured, Chloroflexi_uncultured, Subgroup_6_norank, Subgroup_18_norank, Bacteroidetes_vadinHA17_norank, BSV26_norank, and Sva0485_norank; further, these dominant species did not significantly differ between the two rice varieties (Table 2 ). Above a $0.5 \%$ frequency, we found only the following additional bacterial genera were significantly different at the $p=0.05$ level in the soil samples of the two rice varieties: SC-I-84_norank, Subgroup_7_norank, 
Table 1 Comparison of soil $\mathrm{pH}$, total $\mathrm{C}$, total $\mathrm{N}$, and $\mathrm{P}$, Olsen-P, orthophosphate and organic-P (PME: Phosphomonoesters, PDE: Phosphodiesters, and Pyrophosphate) at the end of the season in fields planted to one of two rice varieties.

\begin{tabular}{|c|c|c|c|c|c|c|c|c|c|}
\hline Variety & $\mathrm{pH}$ & $\begin{array}{l}\text { Total C } \\
\left(\mathrm{mg} \mathrm{g}^{-1}\right)\end{array}$ & $\begin{array}{l}\text { Total N } \\
\left(\mathrm{mg} \mathrm{g}^{-1}\right)\end{array}$ & $\begin{array}{l}\text { Total P } \\
\left(\mathrm{mg} \mathrm{g}^{-1}\right)\end{array}$ & $\begin{array}{l}\text { Olsen-P } \\
\left(\mathrm{mg} \mathrm{kg}^{-1}\right)\end{array}$ & $\begin{array}{l}\text { Orthophosphate } \\
\left(\mathrm{mg} \mathrm{kg}^{-1}\right)\end{array}$ & $\begin{array}{l}\mathrm{PME} \\
\left(\mathrm{mg} \mathrm{g}^{-1}\right)\end{array}$ & $\begin{array}{l}\mathrm{PDE} \\
\left(\mathrm{mg} \mathrm{g}^{-1}\right)\end{array}$ & $\begin{array}{l}\text { Pyrophosphate } \\
\left(\mathrm{mg} \mathrm{g}^{-1}\right)\end{array}$ \\
\hline XS-134 & $\begin{array}{l}5.411 \\
\pm 0.031 \mathrm{~b}\end{array}$ & $\begin{array}{l}25.594 \\
\pm 1.606 \text { a }\end{array}$ & $\begin{array}{l}2.771 \\
\pm 0.167 \mathrm{a}\end{array}$ & $\begin{array}{l}0.443 \\
\pm 0.071 \mathrm{a}\end{array}$ & $\begin{array}{l}7.380 \\
\pm 2.291 \mathrm{a}\end{array}$ & $\begin{array}{l}197 \\
\pm 55 \mathrm{a}\end{array}$ & $\begin{array}{l}0.062 \\
\pm 0.005 \mathrm{a}\end{array}$ & $\begin{array}{l}0.009 \\
\pm 0.002 \mathrm{a}\end{array}$ & $\begin{array}{l}0.002 \\
\pm 0.001 \mathrm{a}\end{array}$ \\
\hline YD-1 & $\begin{array}{l}5.483 \\
\pm 0.064 \text { a }\end{array}$ & $\begin{array}{l}23.744 \\
\pm 1.475 \mathrm{~b}\end{array}$ & $\begin{array}{l}2.185 \\
\pm 0.154 \mathrm{~b}\end{array}$ & $\begin{array}{l}0.365 \\
\pm 0.018 \mathrm{~b}\end{array}$ & $\begin{array}{l}6.710 \\
\pm 1.322 \mathrm{a}\end{array}$ & $\begin{array}{l}153 \\
\pm 22 \mathrm{~b}\end{array}$ & $\begin{array}{l}0.056 \\
\pm 0.007 \mathrm{~b}\end{array}$ & $\begin{array}{l}0.011 \\
\pm 0.003 \mathrm{a}\end{array}$ & $\begin{array}{l}0.003 \\
\pm 0.001 \mathrm{a}\end{array}$ \\
\hline
\end{tabular}

Means followed by same lowercase letter is not significantly different between the two rice varieties for each soil parameter $(p>0.05)$.

Acidobacteriaceae_Subgroup_1_uncultured, Candidatus_Solibacter, Bryobacter, Desulfuromonadales_unclassified, and Subgroup_17_norank. Despite their significance, these 7 genera when combined occupied only $7.3 \%$ and $5.9 \%$ of the total sequences for the $\mathrm{XS}-134$ and $\mathrm{YD}-1$ rice varieties, respectively (Table 2 ). However, when comparing OTUs, the Ace and Shannon index revealed that the diversity of soil bacterial communities in YD-1 was higher than that of XS-134 (Table 3).

3.4 Relationship between nutrient uptake and residue and soil bacteria

In a correlation analysis of OTU data, the Ace and Shannon index demonstrated that the total soil residual $\mathrm{P}$, total- $\mathrm{N}$, and Ortho-P were negatively correlated with bacterial community diversity; however, the $\mathrm{pH}$ of the soil, plant Grain-P, Grain-N, and Straw-P were positively correlated with bacterial community diversity (Table 4). The results of a network analysis further showed that the total soil residual $P$ was significantly, positively, and directly associated with Bryobacter, which represented $0.9 \%$ and $0.8 \%$ of the bacterial sequences in the soil samples of XS-134 and YD-1 (Fig. 5, Table 5). The association route can be denoted by i) total soil $\mathrm{P}$ - Bryobacter - Bradyrhizobium-SC-I-84-norank - rice straw or ii) total soil P - Bryobacter - Subgroup-7-norank - Bradyrhizobium - SC-I84-norank - rice straw. In these bacterial genera, only the Subgroup-7-norank and SC-I-84-norank had a frequency that was above $1 \%$, and Bryobacter and Bradyrhizobium were both found to be non-dominant bacteria in tested rice of wetland soils (Table 4). At the same time, in the microbial network structure, the total $\mathrm{P}$ of the soil was indirectly associated with one dominant strain (Nitrospira), and other non-dominant strains, such as Subgroup-7-norank, Bradyrhizobium, SC-I-84-norank, GR-WP33-30-norank, and Aquicella, and straw biomass as well. Significant relationships were also found between Nitrospira (dominant bacteria) and Bryobacter, and between Subgroup-7-norank (dominant bacteria) and Chloroflexi_uncultured (dominant bacteria), though these three dominant bacteria had no association with the total $\mathrm{N}$ of the soil (Table 5). Moreover, network relationships among the $\mathrm{pH}$ of the soil, the total $\mathrm{N}$, Straw-N, Grain-N, and Grain-P were part of a different module than the network that had included the total P content (Fig. 5).

\section{Discussion}

4.1 Feasibility of using rice variety YD-1 to reduce soil residual nutrients

This study highlighted that it is efficient to use the rice variety (YD-1) with a high straw biomass for one season to allow more uptake of nutrients from the soil. After planting YD-1 for one season, the total $\mathrm{N}$ and $\mathrm{P}$ content of the soil was decreased by $22.1 \%$ and $9.8 \%$, respectively, compared to the rice variety XS-134, which was grown prior to 2016 (Table 1). Compared to the conventional rice variety XS-134, YD-1 could remove more $\mathrm{N}$ and $\mathrm{P}$ from paddy wetlands via harvesting, which effectively lowered the total $\mathrm{N}$ and $\mathrm{P}$ content that remained in the soil (Fig. 1, Table 1). In the research site in the Taihu Lake region, the local rice straw biomass is generally less than 10 $\mathrm{t} \mathrm{ha}^{-1}$, and compared to the California rice growing area, we observed that rice straw was in the range of 9.1-11.7 $\mathrm{t} \mathrm{ha}^{-1}$ across four sites (Liang et al., 2014), which were all lower than that of the YD-1 used in this study. Therefore, the rice variety YD-1 has the potential to reduce the leaching of $N$ and $P$ from agricultural wetlands, as well as the eutrophication risk.

Regarding $\mathrm{P}$, in the present study, orthophosphate and phosphomonoester were the main inorganic and organic forms of $P$ in the paddy wetland soils, respectively. Rice variety YD-1 significantly reduced the residual levels of $P$ in the soil, especially levels of orthophosphate, which were reduced by $44 \mathrm{mg} \mathrm{kg}^{-1}$ compared to the reduction by XS-134 (Table 1). Orthophosphate included not only available plant $P$, but also some insoluble $\mathrm{P}$ forms, such as iron phosphate and calcium phosphate (Traina et al., 1986). A previous study found that, the presence of large amounts of iron and aluminum oxides and other substances in acid soils had a strong fixation effect on soil P (Freese et al., 1992; Yuan and Lavkulich, 1994), thereby reducing the plant availability of $P$. However, in this research study, the plant available $P$ contents of the respective soil samples of XS-134 and YD-1 were both higher than the critical Olsen-P value $\left(5 \mathrm{mg} \mathrm{kg}^{-1}\right)$ for acid soils (Dobermann and Fairhurst, 2000), and there was no significant difference in the soil Olsen-P content between the two rice varieties (XS-134 and YD-1) (Table 1). This may be related to the equilibrium relationship between the release of available $\mathrm{P}$ from total $\mathrm{P}$ (including orthophosphate, monophosphate, etc.) and uptake by the rice plant (Stewart 


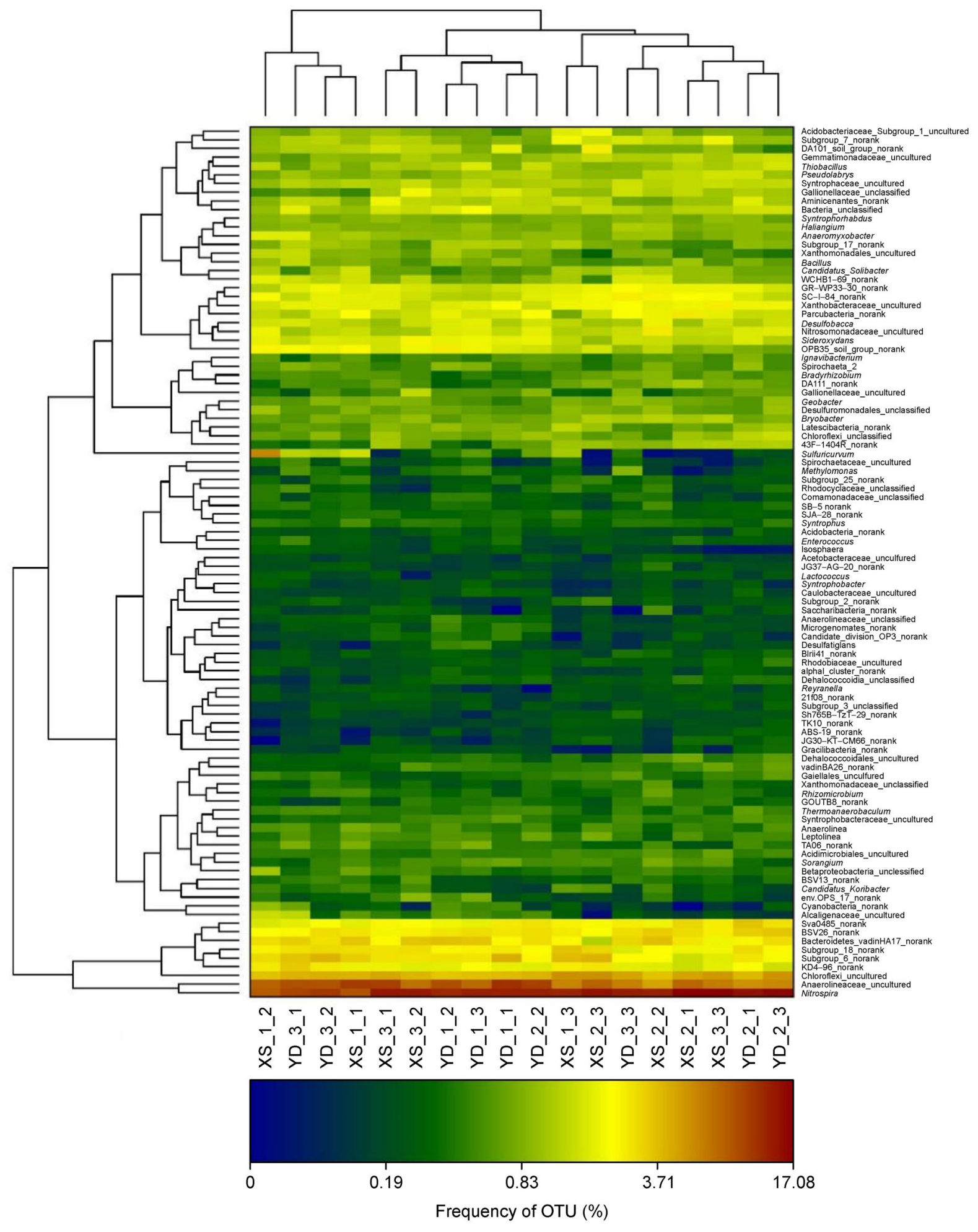

Fig. 2 The relative abundance of microbial clusters at the genus level (rows) in 18 samples (columns) from rice paddy wetlands. Sample names beginning with $\mathrm{X}$ indicate fields planted to Xiushui-134, and names beginning with $\mathrm{Y}$ indicate Yudao-1. 


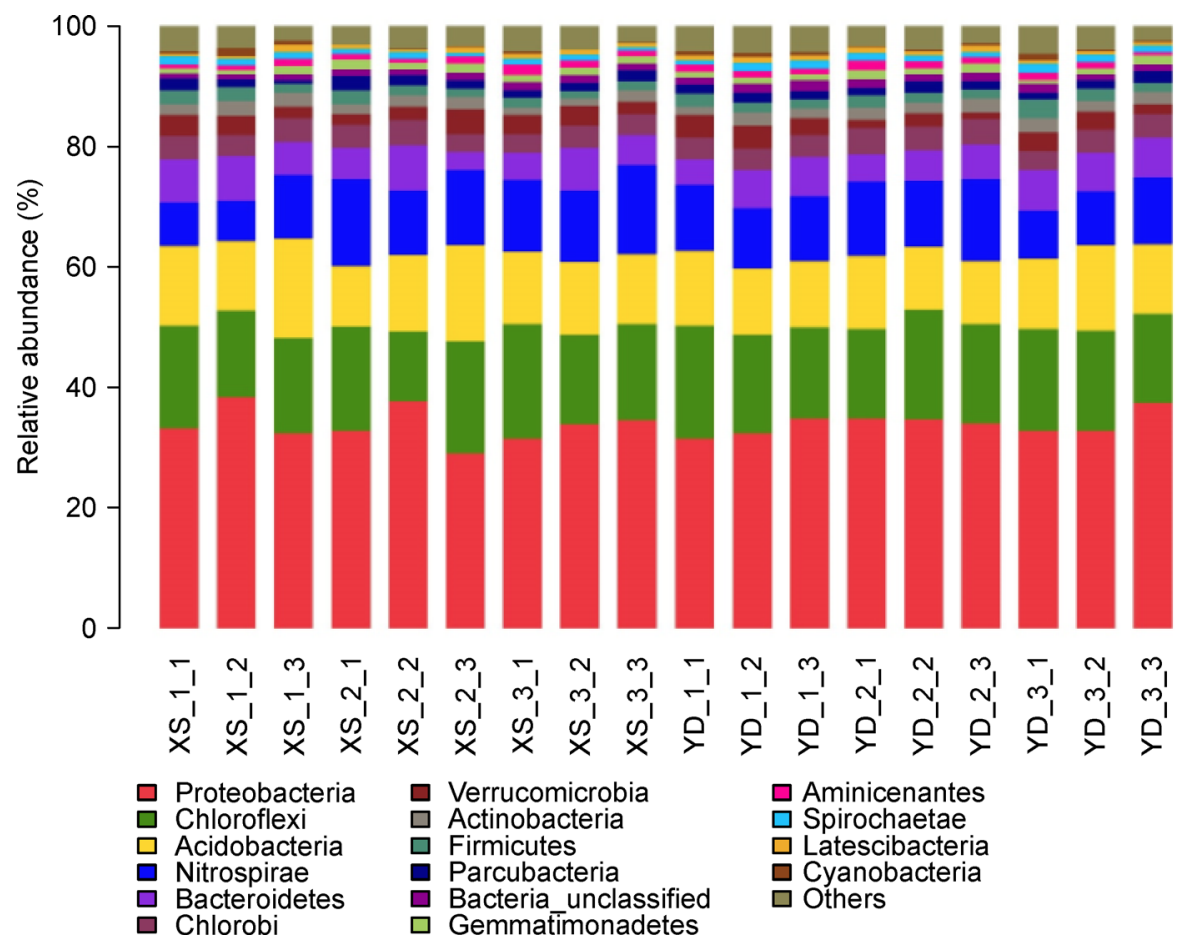

Fig. 3 Microbial community structure at the phylum level in soils planted to one of two rice varieties. Sample names beginning with $\mathrm{X}$ indicate fields planted to Xiushui-134, and names beginning with $\mathrm{Y}$ indicate Yudao-1.

and Tiessen, 1987). Previous studies have shown that, apart from some organic $\mathrm{P}$ species with low molecular weight, most organic $\mathrm{P}$ could not be absorbed and utilized by plants until it was bio-transformed into inorganic $P$ (Makarov et al., 2005).

\subsection{Connection of nutrient and soil bacterial community structure}

The diversity of soil bacterial communities of the rice variety YD-1 was higher than that of XS-134 (Table 3), which was associated with a decrease in the total soil $\mathrm{P}$ and $\mathrm{N}$ in paddy wetlands (Table 2). However, the change in bacterial community diversity was mainly caused by a change in the nondominant species, and there was no significant difference in the frequency of dominant bacteria between the two rice varieties (Table 4). These results indicate that the rice variety YD-1 had no significant effect on the dominant bacterial communities in tested paddy wetlands, which may be due to the sufficient background nutrients in the paddy soil of the experimental area. Before planting of the rice variety YD-1, the total soil $\mathrm{N}$ and $\mathrm{P}$ concentrations were as high as $2.81 \mathrm{mg} \mathrm{g}^{-1}$ and $0.41 \mathrm{mg} \mathrm{g}^{-1}$, respectively. Generally, the contribution of crop varieties that affect the microbial community, which includes bacteria, is higher in low-fertile soils (Yao et al., 2018; Chowdhury et al., 2019).

To determine the connection between nutrient and microbial community structures, a network analysis was used. However, only a simple network module was found among the total $\mathrm{P}$ of the soil, soil bacteria, and the rice straw biomass (Fig. 5), possibly due to the condition of soil with high nutrient content. Among soil bacteria, Bryobacter and Bradyrhizobium have direct and indirect associations with the total $P$ of the soil. Further, Bryobacter is a peat-inhabiting, aerobic chemoorganotroph Acidobacteria that was first isolated from a sphagnum peat bog sample obtained in the Bakchar Tomsk region of Russia in 2005 (Kulichevskaya et al., 2010), and to date its ecological implications are unknown. Bradyrhizobium is the genus of Gram-negative nodule bacteria that fix atmospheric $\mathrm{N}$ in root nodules of legume plants and enhance soil $\mathrm{N}$ levels. Nitrospira, as a dominant bacterium in paddy soil, has been widely reported as responsible for nitrite oxidation in biogeochemical $\mathrm{N}$ cycling in agricultural ecosystems (Han et al., 2017; Zhang et al., 2017). In this study, Nitrospira was also indirectly associated with the total $\mathrm{P}$ content of the soil, indicating Nitrospira is sensitive to land management, even in acid, high-fertile paddy soil. This finding is in accordance with that of Han et al. (2017), which also found that the abundance of Nitrospira was always greater than that of other bacteria, such as Nitrobacter, and that its abundance was affected by rice-growing and straw incorporation, while that of Nitrobacter was not.

4.3 Perspectives on using rice variety with a high straw biomass

Under the current practice of fertilizer application (a high input of fertilizer), the issue of a soil nutrient surplus in agricultural wetlands and its associated non-point source pollution cannot be completely solved, unless continuous changes in the planting patterns of rice varieties are implemented. The 


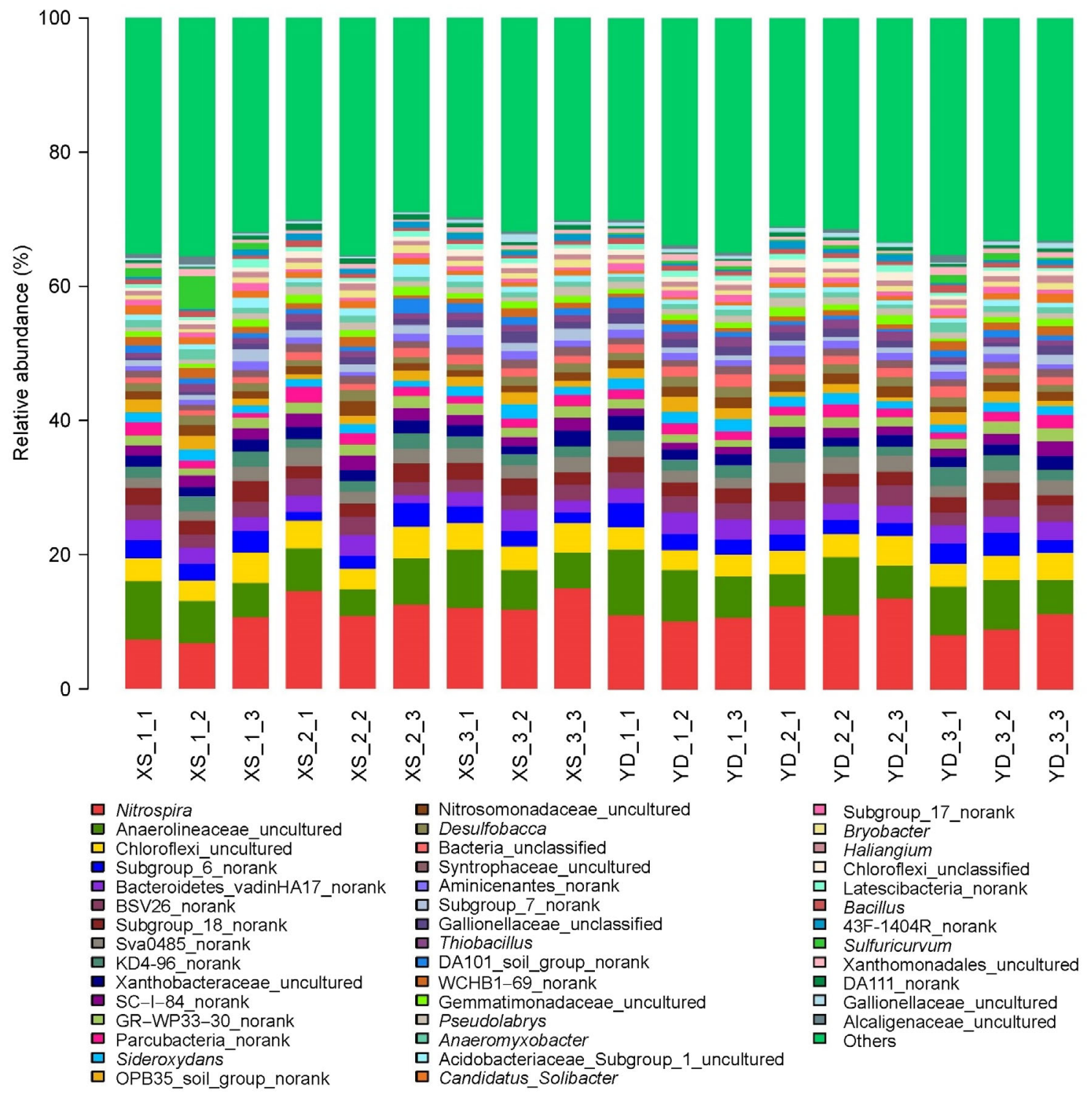

Fig. 4 Microbial community structure at the genus level in soils planted to one of two rice varieties. Sample names beginning with $\mathrm{X}$ indicate fields planted to Xiushui-134, and names beginning with $\mathrm{Y}$ indicate Yudao-1.

number of seasons that can be continuously planted with YD-1 still depends on its impact on nutrient and microbial community structures. In this study, we only collected rhizosphere soil after the harvest (maturity) of rice plants to investigate any seasonal effects. However, the microbial diversity that was presented after the harvest may be different from that of the stage where roots are more active in terms of nutrient uptake, such as stages of early vegetation to flowering. Thus, it would be better if these different stages are taken into account when evaluating the impact of rice variety on microbial community structures.

Another concern is whether the rice straw was retained. In this study, rice straw was harvested for the environmental purpose of the net removal of nutrients from the rice field system. In most conservation agriculture systems, straw mulch seems to be significantly retained in cropping fields to maintain soil fertility (Campiglia et al., 2014; Palm et al., 2014; Pittelkow et al., 2015). Under this type of management, high biomass production with more $\mathrm{C}$ supplies may stimulate more microbial activity (Tejada and Benitez, 2014; Singh et al., 2016). Thus, it is expected that the relationships between nutrient availability, plant growth, $\mathrm{C}$ release, and microbial changes and activities differ from those of this study.

The present study was based on a short-term assessment and validated the possibility for future use of rice straw to immobilize non-point source pollutants, such as $\mathrm{N}$ and $\mathrm{P}$ 
Table 2 Bacterial abundance in soils planted to one of two rice varieties.

\begin{tabular}{|c|c|c|c|}
\hline & Variety XS-134 & Variety YD-1 & $p$-value \\
\hline Nitrospira & $11.28 \pm 2.79$ & $10.77 \pm 1.65$ & 0.536 \\
\hline Anaerolineaceae_uncultured & $6.33 \pm 1.57$ & $6.84 \pm 1.76$ & 0.659 \\
\hline Chloroflexi_uncultured & $3.85 \pm 0.63$ & $3.54 \pm 0.44$ & 0.377 \\
\hline Subgroup_6_norank & $2.43 \pm 0.75$ & $2.58 \pm 0.65$ & 0.825 \\
\hline Subgroup_18_norank & $2.34 \pm 0.45$ & $2.18 \pm 0.34$ & 0.596 \\
\hline Bacteroidetes_vadinHA17_norank & $2.34 \pm 0.66$ & $2.59 \pm 0.36$ & 0.288 \\
\hline BSV26_norank & $2.26 \pm 0.31$ & $2.51 \pm 0.31$ & 0.064 \\
\hline Sva0485_norank & $2.02 \pm 0.39$ & $2.16 \pm 0.51$ & 0.536 \\
\hline KD4-96_norank & $1.83 \pm 0.37$ & $1.86 \pm 0.45$ & 1.000 \\
\hline SC-I-84_norank & $1.76 \pm 0.24$ & $1.40 \pm 0.38$ & 0.027 \\
\hline Xanthobacteraceae_uncultured & $1.68 \pm 0.32$ & $1.67 \pm 0.21$ & 0.965 \\
\hline GR-WP33-30_norank & $1.57 \pm 0.22$ & $1.51 \pm 0.28$ & 0.536 \\
\hline Parcubacteria_norank & $1.48 \pm 0.49$ & $1.47 \pm 0.31$ & 0.860 \\
\hline OPB35_soil_group_norank & $1.39 \pm 0.48$ & $1.39 \pm 0.56$ & 0.930 \\
\hline Sideroxydans & $1.36 \pm 0.35$ & $1.48 \pm 0.23$ & 0.200 \\
\hline Nitrosomonadaceae_uncultured & $1.33 \pm 0.41$ & $1.38 \pm 0.23$ & 0.377 \\
\hline Subgroup_7_norank & $1.25 \pm 0.35$ & $0.92 \pm 0.26$ & 0.027 \\
\hline Desulfobacca & $1.20 \pm 0.26$ & $1.29 \pm 0.20$ & 0.354 \\
\hline Syntrophaceae_uncultured & $1.12 \pm 0.17$ & $1.11 \pm 0.13$ & 0.566 \\
\hline Bacteria_unclassified & $1.09 \pm 0.24$ & $1.35 \pm 0.28$ & 0.052 \\
\hline DA101_soil_group_norank & $1.09 \pm 0.52$ & $0.87 \pm 0.40$ & 0.354 \\
\hline WCHB1-69_norank & $1.05 \pm 0.37$ & $0.87 \pm 0.34$ & 0.200 \\
\hline Aminicenantes_norank & $1.05 \pm 0.38$ & $1.12 \pm 0.25$ & 0.596 \\
\hline Acidobacteriaceae_Subgroup_1_uncultured & $1.03 \pm 0.41$ & $0.67 \pm 0.15$ & 0.010 \\
\hline Gemmatimonadaceae_uncultured & $1.00 \pm 0.21$ & $0.91 \pm 0.27$ & 0.536 \\
\hline Gallionellaceae_unclassified & $0.96 \pm 0.43$ & $1.09 \pm 0.34$ & 0.216 \\
\hline Thiobacillus & $0.96 \pm 0.17$ & $1.05 \pm 0.33$ & 0.479 \\
\hline Candidatus_Solibacter & $0.94 \pm 0.24$ & $0.66 \pm 0.29$ & 0.042 \\
\hline Pseudolabrys & $0.93 \pm 0.28$ & $0.98 \pm 0.21$ & 0.536 \\
\hline Bryobacter & $0.89 \pm 0.22$ & $0.67 \pm 0.14$ & 0.034 \\
\hline Anaeromyxobacter & $0.89 \pm 0.27$ & $0.89 \pm 0.23$ & 1.000 \\
\hline Sulfuricurvum & $0.86 \pm 1.59$ & $0.52 \pm 0.34$ & 0.216 \\
\hline 43F-1404R_norank & $0.79 \pm 0.30$ & $0.58 \pm 0.33$ & 0.289 \\
\hline Haliangium & $0.76 \pm 0.09$ & $0.80 \pm 0.11$ & 0.250 \\
\hline Syntrophorhabdus & $0.76 \pm 0.08$ & $0.71 \pm 0.10$ & 0.157 \\
\hline Desulfuromonadales_unclassified & $0.73 \pm 0.12$ & $0.60 \pm 0.13$ & 0.034 \\
\hline Chloroflexi_unclassified & $0.71 \pm 0.20$ & $0.83 \pm 0.27$ & 0.508 \\
\hline Latescibacteria_norank & $0.70 \pm 0.25$ & $0.73 \pm 0.18$ & 0.536 \\
\hline Geobacter & $0.69 \pm 0.08$ & $0.61 \pm 0.19$ & 0.216 \\
\hline Subgroup_17_norank & $0.66 \pm 0.24$ & $0.93 \pm 0.15$ & 0.027 \\
\hline DA111_norank & $0.64 \pm 0.23$ & $0.46 \pm 0.15$ & 0.058 \\
\hline Bacillus & $0.64 \pm 0.17$ & $0.75 \pm 0.21$ & 0.233 \\
\hline Xanthomonadales_uncultured & $0.62 \pm 0.25$ & $0.73 \pm 0.27$ & 0.377 \\
\hline Bradyrhizobium & $0.56 \pm 0.11$ & $0.45 \pm 0.14$ & 0.093 \\
\hline Ignavibacterium & $0.50 \pm 0.1$ & $0.49 \pm 0.14$ & 0.723 \\
\hline Sorangium & $0.49 \pm 0.11$ & $0.41 \pm 0.14$ & 0.157 \\
\hline Betaproteobacteria_unclassified & $0.49 \pm 0.18$ & $0.35 \pm 0.05$ & 0.027 \\
\hline Spirochaeta_2 & $0.49 \pm 0.1$ & $0.63 \pm 0.17$ & 0.077 \\
\hline Gallionellaceae_uncultured & $0.46 \pm 0.31$ & $0.56 \pm 0.18$ & 0.063 \\
\hline
\end{tabular}

Results of a $t$-test comparing soils from each variety are shown for OTUs with frequency for at least one variety greater than $0.5 \%$. 
Table 3 Number of Operational Taxonomic Units (OTUs) observed, and Ace and Shannon indices of soil samples.

\begin{tabular}{llll}
\hline Samples & Number of OTUs & Ace & Shannon \\
\hline XS_1_1 & 2223 & 2815 & 6.74 \\
XS_1_2 & 2149 & 2797 & 6.58 \\
XS_1_3 & 2165 & 2847 & 6.70 \\
XS_2_1 & 2136 & 2760 & 6.58 \\
XS_2_2 & 2060 & 2617 & 6.68 \\
XS_2_3 & 2029 & 2712 & 6.57 \\
XS_3_1 & 2150 & 2810 & 6.60 \\
XS_3_2 & 2145 & 2741 & 6.66 \\
XS_3_3 & 2055 & 2653 & 6.54 \\
Mean & 2124 b & $2750 \mathrm{~b}$ & $6.63 \mathrm{~b}$ \\
YD_1_1 & 2222 & 2946 & 6.60 \\
YD_1_2 & 2275 & 2848 & 6.80 \\
YD_1_3 & 2256 & 2882 & 6.77 \\
YD_2_1 & 2149 & 2852 & 6.63 \\
YD_2_2 & 2243 & 2827 & 6.70 \\
YD_2_3 & 2155 & 2736 & 6.69 \\
YD_3_1 & 2251 & 2815 & 6.74 \\
YD_3_2 & 2259 & 2859 & 6.74 \\
YD_3_3 & 2166 & 2809 & 6.70 \\
Mean & $2220 \mathrm{a}$ & $2842 \mathrm{a}$ & $6.71 \mathrm{a}$ \\
\hline
\end{tabular}

The total number of sequences in each sample was 16199. Sample names beginning with $X$ indicate fields planted to Xiushui-134, and names beginning with $\mathrm{Y}$ indicate Yudao-1. Means followed by same lowercase letter is not significantly different between the two rice varieties $(p>0.05)$.

Table 4 Correlation coefficients from evaluations of the relationship between soil and plant factors in rice paddy fields and measures of diversity (total number of OTUs, and Ace and Shannon indices).

\begin{tabular}{llll}
\hline & Number of OTUs & Ace & Shannon \\
\hline $\mathrm{pH}$ & $0.558^{*}$ & 0.398 & $0.507^{*}$ \\
Total C & -0.411 & -0.303 & $-0.480^{*}$ \\
Total N & $-0.681^{\star *}$ & $-0.572^{*}$ & $-0.608^{\star *}$ \\
Total P & $-0.585^{*}$ & $-0.712^{* *}$ & -0.344 \\
Olsen-P & -0.159 & -0.389 & -0.057 \\
Organic-P & -0.430 & -0.250 & -0.387 \\
Orthophosphate & $-0.525^{*}$ & -0.454 & -0.447 \\
PME & -0.345 & -0.371 & -0.340 \\
PDE & 0.127 & 0.061 & 0.088 \\
Pyrophosphate & 0.038 & -0.071 & 0.195 \\
Straw-P & $0.541^{*}$ & 0.443 & $0.483^{*}$ \\
Grain-P & $0.667^{* *}$ & $0.612^{* *}$ & 0.437 \\
Straw-N & -0.034 & -0.146 & -0.053 \\
Grain-N & $0.512^{*}$ & 0.391 & 0.357 \\
Straw-C & 0.464 & 0.379 & 0.252 \\
Grain-C & 0.405 & 0.161 & 0.243 \\
Straw-yield & 0.349 & 0.226 & 0.317 \\
Grain-yield & 0.060 & 0.229 & 0.179 \\
\hline
\end{tabular}

* indicates $p<0.05$, ** indicates $p<0.01$ 
Table 5 Selected interactions (absolute value of correlation coefficient $>0.25$ and $p<0.001$ ) between OTU nodes, or between OTUs and other soil and plant parameters.

\begin{tabular}{|c|c|}
\hline Interaction & Correlation coefficient \\
\hline Gemmatimonas and Chloroflexi-uncultured & 0.913 \\
\hline Draconibacteriaceae-uncultured and Sh765B-TzT-29-norank & -0.913 \\
\hline Roseomonas and Alcaligenaceae-uncultured & 0.907 \\
\hline TK10-norank and Chloroflexi-uncultured & 0.902 \\
\hline Roseomonas and Gemmatimonadaceae-uncultured & -0.885 \\
\hline JG30-KF-CM66-norank and Chloroflexi-uncultured & 0.877 \\
\hline Spirochaetaceae-uncultured and Bacteroidetes-BD2-2-norank & 0.877 \\
\hline Total-P and Orthophosphate & 0.876 \\
\hline 43F-1404R-norank and JG30-KF-CM66-norank & 0.863 \\
\hline 43F-1404R-norank and Nitrospira & 0.834 \\
\hline Acidibacter and DA111-norank & 0.810 \\
\hline Thermoanaerobaculum and Deltaproteobacteria-unclassified & 0.807 \\
\hline Chloroflexi-unclassified and Sva0485-norank & 0.799 \\
\hline GR-WP33-30-norank and Sh765B-TzT-29-norank & 0.789 \\
\hline Total-P and Olsen-P & 0.775 \\
\hline Gemmatimonadaceae-uncultured and TK10-norank & 0.774 \\
\hline KD4-96-norank and Subgroup-6-norank & 0.766 \\
\hline Desulfobacca and SB-5-norank & 0.752 \\
\hline SC-I-84-norank and Bradyrhizobium & 0.744 \\
\hline vadinBA26-norank and Dehalococcoidia-unclassified & 0.732 \\
\hline Aquicella and SC-I-84-norank & 0.727 \\
\hline Subgroup-7-norank and Bryobacter & 0.709 \\
\hline Nitrospira and Bryobacter & 0.707 \\
\hline Bryobacter and Bradyrhizobium & 0.690 \\
\hline BSV13-norank and WCHB1-69-norank & 0.688 \\
\hline SC-I-84-norank and Straw & 0.676 \\
\hline Subgroup-7-norank and Bradyrhizobium & 0.662 \\
\hline Subgroup-7-norank and Chloroflexi-uncultured & 0.637 \\
\hline Total-N and total-C & 0.635 \\
\hline Grain-P and grain-N & 0.628 \\
\hline JG30-KF-CM66-norank and Bacteroidetes-unclassified & 0.608 \\
\hline Bacteroidetes-unclassified and Chloroflexi-uncultured & 0.608 \\
\hline Gemmatimonadaceae-uncultured and Alcaligenaceae-uncultured & 0.591 \\
\hline Gallionellaceae-unclassified and Syntrophobacteraceae-uncultured & 0.575 \\
\hline Total-P and Bryobacter & 0.502 \\
\hline GR-WP33-30-norank and SC-I-84-norank & 0.419 \\
\hline Xanthomonadales-uncultured and Alcaligenaceae-uncultured & 0.390 \\
\hline Sva0485-norank and Nitrospira & 0.390 \\
\hline Acidobacteriaceae-subgroup-1-uncultured and Candidatus-Koribacter & 0.388 \\
\hline Sva0485-norank and Gemmatimonadaceae-uncultured & 0.361 \\
\hline Enterococcus and Bacillus & 0.359 \\
\hline
\end{tabular}

Pairs in bold font include factors known a priori to be important in nutrient cycling, and may indicate relationships worth exploring in future studies. 


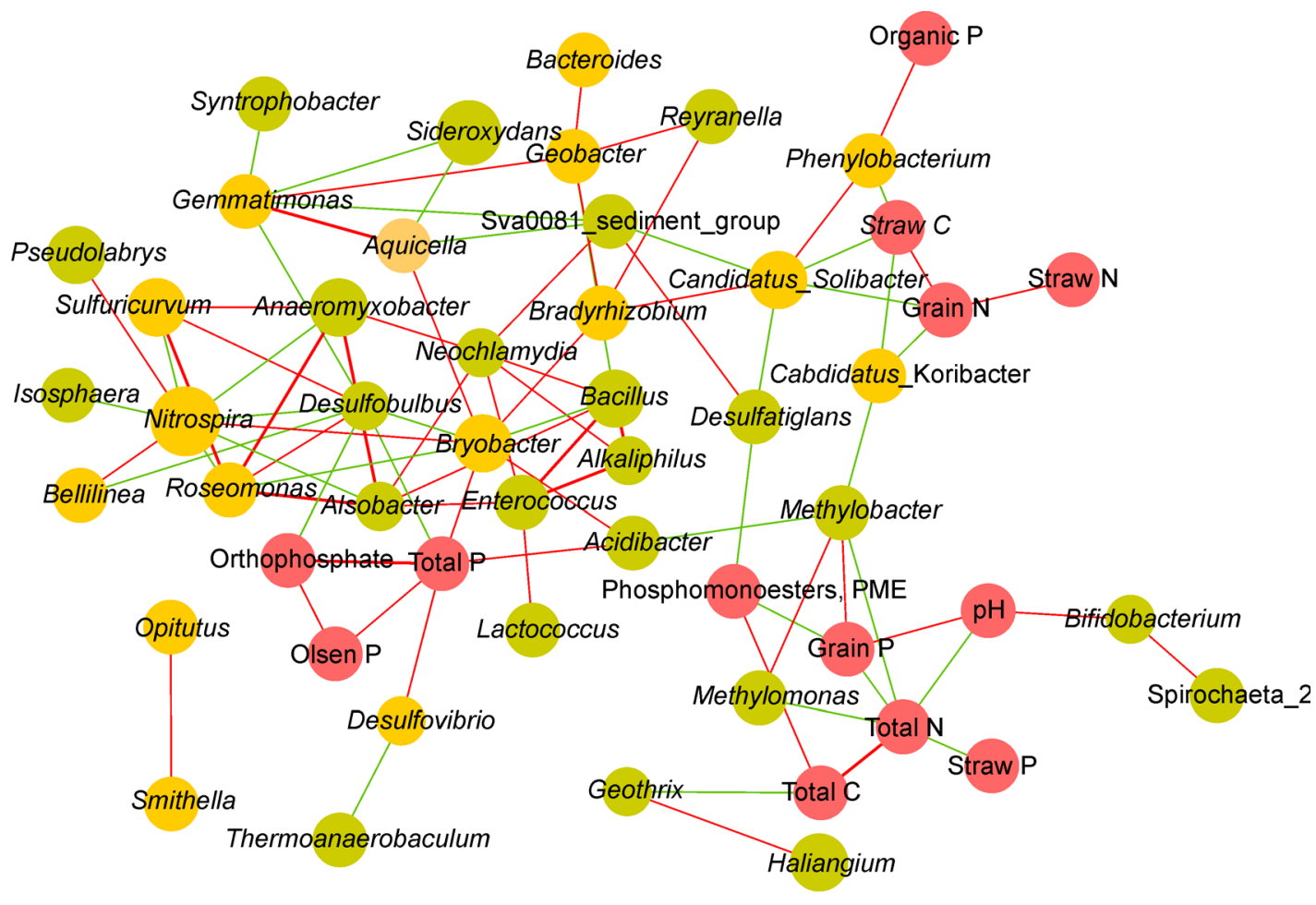

YD

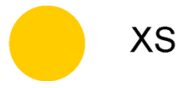

Fig. 5 Network analysis of soil taxa and nutrients observed in associated soil and plants. The size of nodes is proportional to their abundance. Associations between OTU nodes were evaluated based on co-occurrence in samples. Associations between OTUs and the nutrients in soils and plants (red) were based on correlation. Positive and negative associations are indicated by red and green links, respectively. YD indicate fields planted to Yudao-1, XS indicate fields planted to Xiushui-134.

content of soil. We also found that the microbial structure function was not overly disturbed during this process, which was conducive to the sustainability and stability of soil function. Relevant future research is beneficial to the understanding of plant-microbe interactions that drive biogeochemical processes. However, in order to better understand the relationship between rice plant and rhizosphere microbes, long-term assessment is necessary. Future research should begin with metagenomics and conduct longer-term observations to obtain more complete results.

\section{Conclusion}

We observed that the high-straw rice variety (YD-1) consumes more nutrients and causes less total residual $\mathrm{N}$ and $\mathrm{P}$ content of the soil to remain. Under high nutrient status, an effect of rice variety on the frequency of the dominant species of soil bacteria was not observed. The difference in bacterial community diversity between rice varieties was primarily due to changes in non-dominant species. The total P of soil has an indirect association with rice straw biomass via soil nondominant species. Future studies should further investigate the continuous seasonal effects of rice variety changes on the relationships between chemical properties of soil and microbial communities. In addition, this study only focused on rhizosphere soil; thus, additional studies are needed for a comprehensive understanding of microbial communities in root, rhizosphere, and bulk soils.

\section{Conflict of interest}

The authors report no conflict of interest.

\section{Acknowledgments}

We are grateful for grants from the National Key Research and Development Program of China (2017YFD0800103), Natural Science Foundation of Zhejiang Province (LR16B070001), and the National Natural Science Foundation of China (41522108).

\section{References}

Amato, K.R., Yeoman, C.J., Kent, A., Righini, N., Carbonero, F., Estrada, A., Gaskins, H.R., Stumpf, R.M., Yildirim, S., Torralba, M., Gillis, M., Wilson, B.A., Nelson, K.E., White, B.A., Leigh, S.R., 2013. Habitat degradation impacts black howler monkey (Alouatta 
pigra) gastrointestinal microbiomes. ISME Journal 7, 1344-1353.

Balasooriya, W.K., Huygens, D., Rajapaksha, R.M.C.P., Boeckx, P., 2016. Effect of rice variety and fertilizer type on the active microbial community structure in tropical paddy fields in Sri Lanka. Geoderma 265, 87-95.

Benjamini, Y., Hochberg, Y., 1995. Controlling the false discovery ratea practical and powerful approach to multiple testing. Journal of the Royal Statistical Society. Series B. Methodological 57, 289-300.

Bhadraray, S., Purakayastha, T.J., Chhonkar, P.K., Verma, V., 2002. Phosphorus mobilization in hybrid rice rhizosphere compared to high yielding varieties under integrated nutrient management. Biology and Fertility of Soils 35, 73-78.

Breidenbach, B., Pump, J., Dumont, M.G., 2016. Microbial community structure in the rhizosphere of rice plants. Frontiers in Microbiology 6, 1537

Breulmann, M., Schulz, E., Weißhuhn, K., Buscot, F., 2012. Impact of the plant community composition on labile soil organic carbon, soil microbial activity and community structure in semi-natural grassland ecosystems of different productivity. Plant and Soil 352, 253 265.

Brown, M.B., 1975. 400: A method for combining non-independent, one-sided tests of significance. Biometrics 31, 987.

Cade-Menun, B.J., Carter, M.R., James, D.C., Liu, C.W., 2010. Phosphorus forms and chemistry in the soil profile under long-term conservation tillage: a phosphorus-31 nuclear magnetic resonance study. Journal of Environmental Quality 39, 1647-1656.

Campiglia, E., Mancinelli, R., Di Felice, V., Radicetti, E., 2014. Longterm residual effects of the management of cover crop biomass on soil nitrogen and yield of endive (Cichorium endivia L.) and savoy cabbage (Brassica oleracea var. sabauda). Soil \& Tillage Research 139, 1-7

Chowdhury, S. P., Babin, D., Sandmann, M., Jacquiod, S., Sommermann, L., Sørensen, S.J., Fliessbach, A., Mäder, P., Geistlinger, J., Smalla, K., Rothballer, M., Grosch, R., 2019. Effect of long-term organic and mineral fertilization strategies on rhizosphere microbiota assemblage and performance of lettuce. Environmental Microbiology 21, 2426-2439

Chen, H., Wang, G., Lu, X., Jiang, M., Mendelssohn, I.A., 2015. Balancing the needs of China's wetland conservation and rice production. Environmental Science \& Technology 49, 6385-6393.

Conrad, R., 2007. Microbial ecology of methanogens and methanotrophs. Advances in Agronomy 96, 1-63.

Dass, A., Kaur, R., Choudhary, A.K., Pooniya, V., Raj, R., Rana, K.S., 2015. System of rice (Oryza sativa) intensification for enhanced productivity and resource-use-efficiency-A review. Indian Journal of Agronomy 60, 1-19.

Dobermann, A., Fairhurst, T.H., 2000. Rice: Nutrient Disorders and Nutrient Management. Makati City: International Rice Research Institute, Philippines, pp.199

Eisenhauer, N., Bessler, H., Engels, C., Gleixner, G., Habekost, M., Milcu, A., Partsch, S., Sabais, A.C., Scherber, C., Steinbeiss, S., Weigelt, A., Weisser, W.W., Scheu, S., 2010. Plant diversity effects on soil microorganisms support the singular hypothesis. Ecology 91, 485-496.

Faust, K., Raes, J., 2012. Microbial interactions: from networks to models. Nature Reviews Microbiology 10, 538-550.
Faust, K., Sathirapongsasuti, J.F., Izard, J., Segata, N., Gevers, D., Raes, J., Huttenhower, C., 2012. Microbial co-occurrence relationships in the human microbiome. PLoS Computational Biology 8 , e1002606.

Freese, D., Vanderzee, S., Vanriemsdijk, W.H., 1992. Comparison of different models for phosphate sorption as a function of the iron an aluminum-oxides of soils. Journal of Soil Science 43, 729-738.

Han, S., Luo, X., Liao, H., Nie, H., Chen, W., Huang, Q., 2017. Nitrospira are more sensitive than Nitrobacter to land management in acid, fertilized soils of a rapeseed-rice rotation field trial. Science of the Total Environment 599-600, 135-144.

Harish, M.N., Choudhary, A.K., Singh, Y.V., Pooniya, V., Das, A., Varatharajan, T., 2018. Influence of promising rice (Oryza sativa) varieties and nutrient management practices on micronutrient biofortification and soil fertility in Eastern Himalayas. Indian Journal of Agronomy 63, 377-399.

Jennings, P.R., 1974. Rice breeding and world food production. Science 186, 1085-1088.

Ju, X.T., Xing, G.X., Chen, X.P., Zhang, S.L., Zhang, L.J., Liu, X.J., Cui, Z.L., Yin, B., Christie, P., Zhu, Z.L., Zhang, F.S., 2009. Reducing environmental risk by improving $\mathrm{N}$ management in intensive Chinese agricultural systems. Proceedings of the National Academy of Sciences of the United States of America 106, 3041-3046.

Kulichevskaya, I.S., Suzina, N.E., Liesack, W., Dedysh, S.N., 2010. Bryobacter aggregatus gen. nov., sp. nov., a peat-inhabiting, aerobic chemo-organotroph from subdivision 3 of the Acidobacteria. International Journal of Systematic and Evolutionary Microbiology 60, 301-306.

Lange, M., Eisenhauer, N., Sierra, C.A., Bessler, H., Engels, C., Griffiths, R.I., Mellado-Vázquez, P.G., Malik, A.A., Roy, J., Scheu, S., Steinbeiss, S., Thomson, B.C., Trumbore, S.E., Gleixner, G., 2015. Plant diversity increases soil microbial activity and soil carbon storage. Nature Communications 6, 6707.

Liang, X.Q., Chen, Y.X., Li, H., Tian, G.M., Zhang, Z.J., Ni, W.Z., He, M.M., 2007. Nitrogen interception in floodwater of rice field in Taihu region of China. Journal of Environmental Sciences (China) 19, 1474-1481.

Liang, X.Q., Chen, Y.X., Nie, Z.Y., Ye, Y.S., Liu, J., Tian, G.M., Wang, G.H., Tuong, T.P., 2013. Mitigation of nutrient losses via surface runoff from rice cropping systems with alternate wetting and drying irrigation and site-specific nutrient management practices. Environmental Science and Pollution Research International 20, 69806991.

Liang, X.Q., Harter, T., Porta, L., van Kessel, C., Linquist, B.A., 2014. Nitrate leaching in californian rice fields: a field- and regional-scale assessment. Journal of Environmental Quality 43, 881-894.

Liang, X.Q., Jin, Y., He, M.M., Liu, Y., Hua, G.F., Wang, S., Tian, G.M., 2017. Composition of phosphorus species and phosphatase activities in a paddy soil treated with manure at varying rates. Agriculture, Ecosystems \& Environment 237, 173-180.

Lima-Mendez, G., Faust, K., Henry, N., Decelle, J., Colin, S., Carcillo, F., Chaffron, S., Ignacio-Espinosa, J.C., Roux, S., Vincent, F., Bittner, L., Darzi, Y., Wang, J., Audic, S., Berline, L., Bontempi, G., Cabello, A.M., Coppola, L., Cornejo-Castillo, F.M., d'Ovidio, F., De Meester, L., Ferrera, I., Garet-Delmas, M.J., Guidi, L., Lara, E., 
Pesant, S., Royo-Llonch, M., Salazar, G., Sánchez, P., Sebastian, M., Souffreau, C., Dimier, C., Picheral, M., Searson, S., KandelsLewis, S., Gorsky, G., Not, F., Ogata, H., Speich, S., Stemmann, L., Weissenbach, J., Wincker, P., Acinas, S.G., Sunagawa, S., Bork, P., Sullivan, M.B., Karsenti, E., Bowler, C., de Vargas, C., Raes, J., the Tara Oceans coordinators, 2015. Ocean plankton. Determinants of community structure in the global plankton interactome. Science 348, 1262073.

Luo, X.S., Han, S., Fu, X.Q., Li, X., Wang, L., Peng, S.B., Chen, W.L., Huang, X.Y., 2019. The microbial network in naturally fertile paddy soil possibly facilitates functional recruitment in the rice mature stage. Applied Soil Ecology 135, 174-181.

Makarov, M.I., Haumaier, L., Zech, W., Marfenina, O.E., Lysak, L.V., 2005. Can ${ }^{31} \mathrm{P}$ NMR spectroscopy be used to indicate the origins of soil organic phosphates? Soil Biology \& Biochemistry 37, 15-25.

Olsen, S.R., Sommers, L.E., 1982. Phosphorus. In: Page, A.L., Miller, R.H., Keeney, D.R., eds. Methods of Soil Analysis. Part 2 Chemical and Microbiological Properties. Madison, WI:ASASSSA, pp. $403-430$.

Palm, C., Blanco-Canqui, H., DeClerck, F., Gatere, L., Grace, P., 2014. Conservation agriculture and ecosystem services: An overview. Agriculture, Ecosystems \& Environment 187, 87-105.

Pittelkow, C.M., Liang, X., Linquist, B.A., van Groenigen, K.J., Lee, J., Lundy, M.E., van Gestel, N., Six, J., Venterea, R.T., van Kessel, C., 2015. Productivity limits and potentials of the principles of conservation agriculture. Nature 517, 365-368.

Poudel, R., Jumpponen, A., Schlatter, D.C., Paulitz, T.C., Gardener, B. B., Kinkel, L.L., Garrett, K.A., 2016. Microbiome networks: A systems framework for identifying candidate microbial assemblages for disease management. Phytopathology 106, 10831096.

Singh, K., Trivedi, P., Singh, G., Singh, B., Patra, D.D., 2016. Effect of different leaf litters on carbon, nitrogen and microbial activities of sodic soils. Land Degradation \& Development 27, 1215-1226.

Somaweera, K.A.T.N., Suriyagoda, L.D.B., Sirisena, D.N., De Costa, W.A.J.M., 2016. Accumulation and partitioning of biomass, nitrogen, phosphorus and potassium among different tissues during the life cycle of rice grown under different water management regimes. Plant and Soil 401, 169-183.

Stewart, J.W.B., Tiessen, H., 1987. Dynamics of soil organic phosphorus. Biogeochemistry 4, 41-60.

Suriyagoda, L., De Costa, W.A.J.M., Lambers, H., 2014. Growth and phosphorus nutrition of rice when inorganic fertiliser application is partly replaced by straw under varying moisture availability in sandy and clay soils. Plant and Soil 384, 53-68.

Tejada, M., Benitez, C., 2014. Effects of crushed maize straw residues on soil biological properties and soil restoration. Land Degradation \& Development 25, 501-509.
Tilman, D., Cassman, K.G., Matson, P.A., Naylor, R., Polasky, S., 2002. Agricultural sustainability and intensive production practices. Nature 418, 671-677.

Toor, G.S., Condron, L.M., Di, H.J., Cameron, K.C., Cade-Menun, B. J., 2003. Characterization of organic phosphorus in leachate from a grassland soil. Soil Biology \& Biochemistry 35, 1317-1323.

Traina, S.J., Sposito, G., Hesterberg, D., Kafkafi, U., 1986. Effects of $\mathrm{pH}$ and organic acids on orthophosphate solubility in an acidic, montmorillonitic soil. Soil Science Society of America Journal 50, 45-52.

Walker, T.W., Adams, A.F.R., 1958. Studies on soil organic matter: 1. Influence of phosphorus contents of parent materials on accumulations of carbon, nitrogen, sulfur, and organic phosphorus in grassland soils. Soil Science 85, 307-318.

Wang, S.X., Liang, X.Q., Chen, Y.X., Luo, Q.X., Liang, W.S., Li, S., Huang, C.L., Li, Z.Z., Wan, L.L., Li, W., Shao, X.X., 2012. Phosphorus loss potential and phosphatase activity under phosphorus fertilization in long-term paddy wetland agroecosystems. Soil Science Society of America Journal 76, 161-167.

Xiong, Y., Peng, S., Luo, Y., Xu, J., Yang, S., 2015. A paddy eco-ditch and wetland system to reduce non-point source pollution from ricebased production system while maintaining water use efficiency. Environmental Science and Pollution Research International 22, $4406-4417$.

Yao, L., Wang, D., Kang, L., Wang, D., Zhang, Y., Hou, X., Guo, Y., 2018. Effects of fertilizations on soil bacteria and fungi communities in a degraded arid steppe revealed by high through-put sequencing. Peer J 6, e4623.

Ye, Y., Liang, X., Chen, Y., Li, L., Ji, Y., Zhu, C., 2014. Carbon, nitrogen and phosphorus accumulation and partitioning, and $\mathrm{C}: \mathrm{N}: \mathrm{P}$ stoichiometry in late-season rice under different water and nitrogen managements. PLoS One 9, e101776.

Yin, Y., Wang, J., 2016. Changes in microbial community during biohydrogen production using gamma irradiated sludge as inoculum. Bioresource Technology 200, 217-222.

Yuan, G., Lavkulich, L.M., 1994. Phosphate sorption in relation to extractable iron and aluminum in spodosols. Soil Science Society of America Journal 58, 343-346.

Zhang, K.L., Chen, L., Li, Y., Brookes, P.C., Xu, J.M., Luo, Y., 2017. The effects of combinations of biochar, lime, and organic fertilizer on nitrification and nitrifiers. Biology and Fertility of Soils 53, 77 87.

Zhao, J., Ni, T., Li, J., Lu, Q., Fang, Z.Y., Huang, Q.W., Zhang, R.F., Li, R., Shen, B., Shen, Q.R., 2016. Effects of organic-inorganic compound fertilizer with reduced chemical fertilizer application on crop yields, soil biological activity and bacterial community structure in a rice-wheat cropping system. Applied Soil Ecology 99, 1-12 